\title{
Lingua, cultura e testo. Miscellanea di studi francesi in onore di Sergio CIGADA, a cura di Enrica Galazzi e Giuseppe Bernardelli
}

\section{G. Matteo Roccati}

\section{(2) OpenEdition}

Journals

\section{Édition électronique}

URL : http://journals.openedition.org/studifrancesi/32746

DOI : 10.4000/studifrancesi.32746

ISSN : 2421-5856

Éditeur

Rosenberg \& Sellier

\section{Édition imprimée}

Date de publication : 1 décembre 2005

Pagination : 607

ISSN : 0039-2944

\section{Référence électronique}

G. Matteo Roccati, « Lingua, cultura e testo. Miscellanea di studi francesi in onore di Sergio CIGADA, a cura di Enrica Galazzi e Giuseppe Bernardelli », Studi Francesi [En ligne], 147 (XLX | III) | 2005, mis en ligne le 30 novembre 2015, consulté le 19 avril 2021. URL : http://journals.openedition.org/studifrancesi/ 32746 ; DOI : https://doi.org/10.4000/studifrancesi.32746

Ce document a été généré automatiquement le 19 avril 2021.

\section{cc) $(9)$}

Studi Francesi è distribuita con Licenza Creative Commons Attribuzione - Non commerciale - Non opere derivate 4.0 Internazionale. 


\title{
Lingua, cultura e testo. Miscellanea di studi francesi in onore di Sergio CIGADA, a cura di Enrica Galazzi e Giuseppe Bernardelli
}

\author{
G. Matteo Roccati
}

\section{RÉFÉRENCE}

Lingua, cultura e testo. Miscellanea di studi francesi in onore di Sergio CIGADA, a cura di ENRICA GALAZZI e GIUSEPPE BERNARDELLI, Milano, Vita e Pensiero ("Scienze linguistiche e letterature straniere. Ricerche"), 2003, 2 volumi in 3 tomi, pp. XXVIII+1-762, X+1-698, VIII+699-1324.

1 Dans ces mélanges comprenant près d'une centaine de contributions, le volume I rassemble les Studi di lingua, linguistica, storia della lingua, traduttologia, le volume II les Studi di letteratura e di cultura di lingua francese, dont trois études concernent les siècles médiévaux.

2 Anna SLERCA, Remarques sur le motif de l'épée symbolique dans la littérature française $d u$ Moyen Age, vol. II, pp. 1163-1175, passe en revue les occurrences de ce motif littéraire et folklorique.

3 Anna Maria Finoli, «La Fille du comte de Pontieu»: dalla novella al romanzo, vol. II, pp. 531-547, examine avec précision la manière dont le texte a été développé de la version brève à la version longue au XIII ${ }^{\mathrm{e}}$ siècle, notamment dans les dialogues et dans les notations psychologiques. Suit l'examen de la réélaboration romanesque à l'intérieur $\mathrm{du}$ Jehan d'Avennes cyclique au XV $\mathrm{XV}^{\mathrm{e}}$ siècle, où est sensible l'adaptation au goût du milieu bourguignon.

4 Patrizio Tucci, La lode dell'«estat moyen» nella poesia di Eustache Deschamps, vol. II, pp. 1211-1225, mène une étude très fine du topos: proche d'Horace et s'inspirant de Boèce, 
très éloigné de Pétrarque et des humanistes, Deschamps est attentif à la vie matérielle, il utilise, en abandonnant leur aspect abstrait, les modes de pensée qui se trouvent dans le Roman de la Rose et chez Aristote, que Nicole Oresme a traduit et copieusement annoté dans les années 1370-1374. 